\title{
低侵襲人工膝関節置換術支援のための工具経路生成法に関する研究
}

\section{Toolpath Generation Method for Robot-assisted Minimally Invasive Knee Arthroplasty}

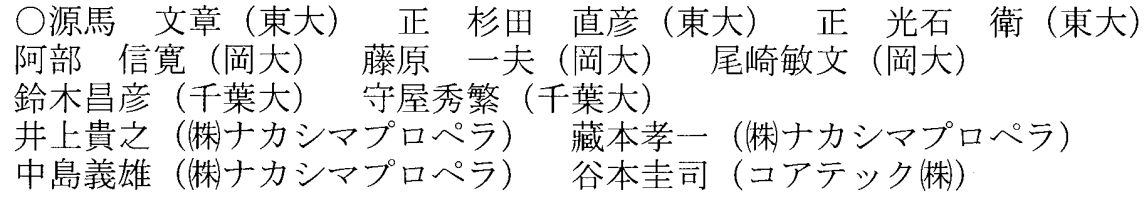

Fumiaki GENMA, Tokyo University, genma@nml.t.u-tokyo.ac.jp Naohiko SUGITA and Mamoru MITSUISHI, Tokyo University Nobuhiro ABE, Kazuo FUJIWARA and Toshifumi OZAKI, Okayama University Masahiko SUZUKI and Hideshige MORIYA, Chiba University

Takayuki INOUE, Kouichi KURAMOTO and Yoshio NAKASHIMA, Nakashima Propeller CO. Ltd.

Keiji TANIMOTO, CORETEC INC.

\begin{abstract}
Toolpath generation and optimization is considered to be a challenging problem in the minimally invasive orthropedic surgery with a milling robot. The objective of this paper is to minimize the collision of the cutting tool with soft tissues. A novel approach of toolpath generation and optimization is proposed. A redundant axis is implemented to avoid collision with the robot. Some important components are modeled based on the physical requirements. A geometric optimization approach based on the model is proposed to improve the toolpath. Software is developed for this application.
\end{abstract}

Key Words: Minimally Invasive Surgery, Toolpath Generation,Artrhoplasty

\section{1. 緒言}

人工膝関節置換術の新しい技術として, 低侵襲手術が注目されてい る.この手法は皮切長を短くすることにより，手術畤の筋肉や軟組織 への負担軽減，リハビリの早期開始，入院期間の短縮などを目的とす るものである. しかしながら，手術の低侵襲化に伴いその難易度も高 くなるため, 手術結果の良否は術者の技量に依る部分が大きい。この ことから，低侵襲手術に対応したメカニカルな手術支援システムへの 期待が高まっている. 本研究では，生体侵襲の軽減およひ回避の観点 から, 狭い手術開創部から周囲組織を損傷させることなく工具を進入 させ，目的の骨切除を完了させる工具経路の生成方法を提案する.

\section{2. 多軸骨切除ロボット}

筆者らは, 低侵襲手術に対応した骨切除支援システムの開発を行っ ており，図1に示寸ように骨切除ロボットは7自由度を有する.このロ

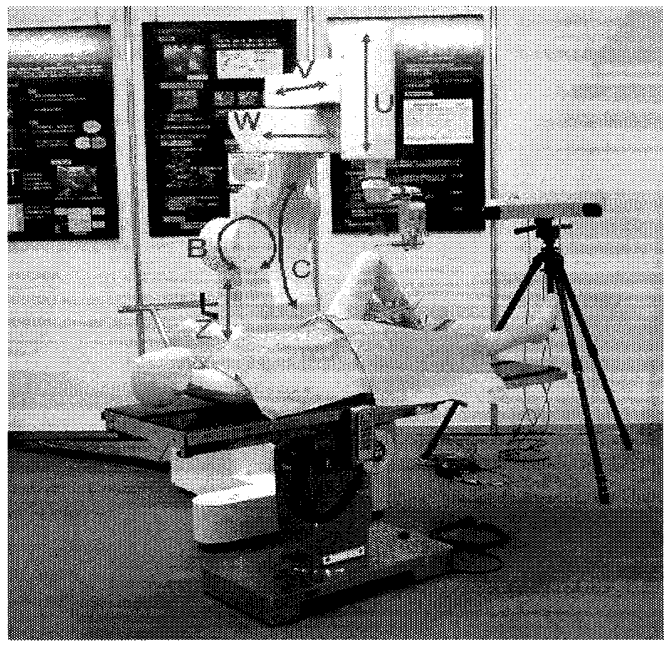

Fig.1 Multi-axis bone cutting robot

ボットは，回転自由度の回転中心の一致といら機構的特徴を有してお り, その軸構成は, 粗動立進1軸 (図中Z軸), 微動並進3軸 (図中U,V,W 軸），および回転 3 軸（図中 $\mathrm{A}, \mathrm{B}, \mathrm{C}$ 軸）である。装置根元より $\mathrm{Z} \rightarrow \mathrm{B} \rightarrow \mathrm{C} \rightarrow \mathrm{U} \rightarrow \mathrm{W} \rightarrow \mathrm{V} \rightarrow \mathrm{A}$ 軸の順に可動部が設置されている.
低侵襲手術では，狭い開創領域からの工具の進入と，対象領域の骨 の切除が課題となる. そのため, 本装置ではこ長となる軸を実装して おり，この軸を含めた各軸を適切に制御することによって，軟部組織 を損傷することなく骨を切除することが可能になると考える.

\section{3. 制約事項と達成事項}

金属加工の分野においては，機械干涉回避のための5 軸制御加工が 研究されており [1]，工具を非干渉領域に接触させることなく，対象 物を加工するという点においては，本研究の目的と一致している。 かしながら，本研究が対象とする医療分野においては，さらに二つの 制約条件がある。一つは，術部が非常に複雑な形状をしており，切除 領域と干涉領域が入り組んだ構造をしていることである．さらに，術 部内部の情報は，術中にならなければ取得できないため，皮切後に術 部をモデル化し，工具経路を生成することが必要となる.
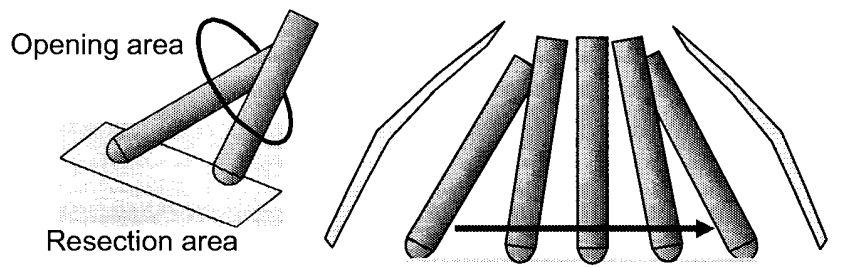

Fig.2 Interpolation by rotational and translational axes

もう一つは, 手術室の空間内に医師や他の医療機器が存在し, ロボ ットの動作範囲に制約がある点である. ロボットの大きな動作は患者 に対する安全面からも避けなければならない，以上の点から，ロボッ 卜の姿勢を決定する回転軸 $\mathrm{B}$ およびC 軸は切除中に動作させないもの とし，回転 A 軸と並進 UWW3 軸による動作を行う。この動作により， 図2のように姿勢変更を最小限に抑えながら軟組織などの障害物を回 避することが可能となる。

達成事項としては, 軟部組織を損傷せずに骨切除が完了可能である こと, 術中の限られた時間内で経路生成処理を行うことが挙げられる. 次に術部情報を取得寸る方法，そしてその情報を考慮した経路生成ア ルゴリズムを提案する. 


\section{4. 軟部組織回避アルゴリズム}

\section{(1) 開創領域の指定}

光学式 3 次元位置計測器(Northern Digital Inc.,Polaris) を用い, 工 具が通過可能と術者が判断した領域を点列で取得する（図3）。得ら れた点群データを基に，重回帰分析を用いて面情報を作成し，面に投 影した点群を含む凸多角形を計算する。 その内部を工具通過可能領域 とする.

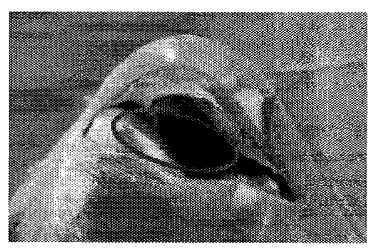

(a) Opening area of knee

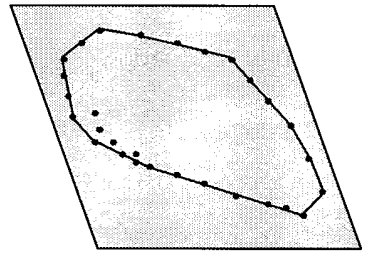

(b) Measured points
Fig.3 Determination of opening area

\section{（2）切除面生成}

工具の切り込み深さに応じて, 切除面は複数面生成される. 例えば, 図 4 (a)の大腿骨遠位端の場合は, 周囲に干渉領域がない部分のため, 仕上げ面と平行に切除面を設定寸ればよい，しかしながら，図4（b) の大腿骨前面の場合は，仕上げ面と平行に切除面を設定すると，軟部 組織と工具が干渉するため，切除面方向を調整する必要が生じる.

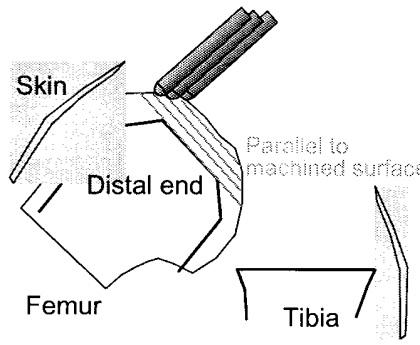

(a) Distal

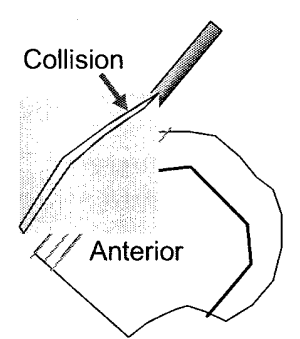

(b) Anterior
Fig.4 Collision of cutting tool and interference

人工溙関節置換術には複数の皮切方法があるが, 開創領域の位置や 形は，それぞれの方法によって大きな差異は生じない[2].したがっ て，図 5 に示寸ように，大腿骨 5 面それぞれに対して，予め工具が通 過する可能性のある開創領域内の有効領域をまず決定する.

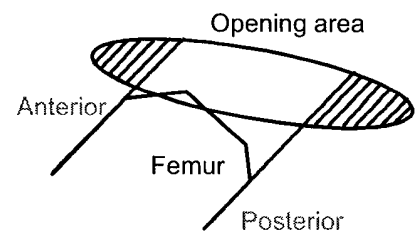

(a) Anterior and posterior

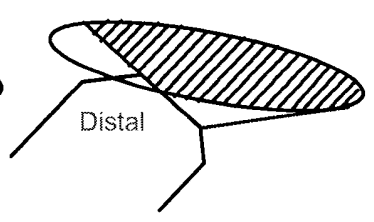

(b) Distal
Fig.5 Available area

この有效領域と仕上げ面の関係から，切除面を決定することが可能 である. 一つの方法として，ある平面に有効領域と仕上げ面を投影し たとき，有效領域内に仕上げ面が最大面積収まるような平面を切除面 と寸る方法が考えられる.この方法により，姿勢変更を最小にする切 除面が生成可能になると考えられるが，面積計算による処理遅延が予 想される，そこで，図6に示寸ように有效領域内にある点を設定し， その点と仕上げ面の原点とを結び，その方向を切除面の法線方向とす る方法を提案する. 設定する点は，有效領域の重心とする場合，ある

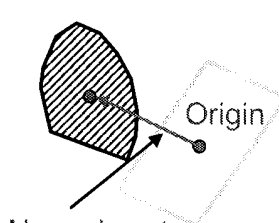

Normal vector

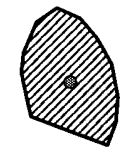

Center of gravity

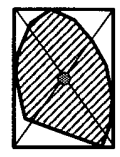

Center of rectangle
Fig. 6 Decision of normal direction

領域を囲む最小長方形の中心とする場合などが考えられるため，実験 的に決定寸る.

\section{(3) 分長軸回転平面設定}

工具姿勢をある方向に決め，工具姿勢を法線とする平面(以下，工 具平面)に有效領域と切除面を投影する. 回転軸は 3 軸あり，圥長軸 (図 1 中A 軸) を適当に制御することにより，図 7 に示寸ように切除 可能領域を自由に設定できる.この時, 最適な切除可能領域の決定は, 図 8 に示寸方法を採用寸る.（a）の方法は，切除面全体の面積に対す る切除可能領域の面積比が最大のものを几長軸方向とするものであ り，(b) の方法は，切除可能範囲長の比を最大にする方向を選択する ものである.

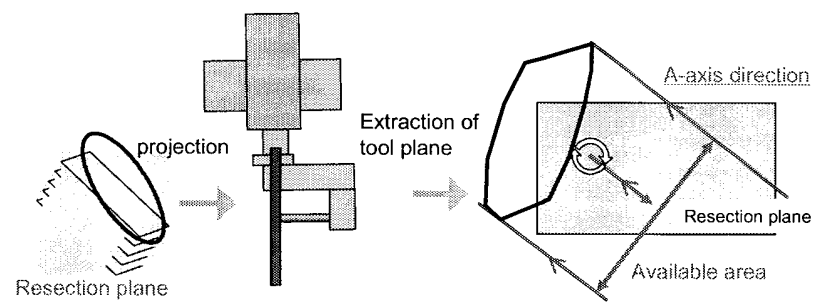

Fig.7 Calculation of resectable area

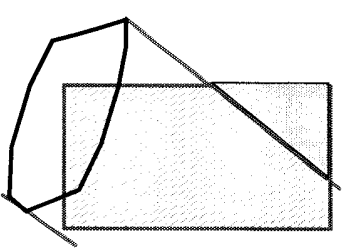

(a) Ratio of area

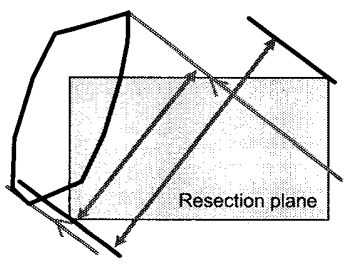

(b) Ratio of length
Fig.8 Determination of resectable area

取りうる全ての工具姿勢から最適な切除領域を決める必要がある ため, 総当り計算を行い，提案方法に従って工具姿勢を一意に決定す る.この処理を全ての切除面に対して行う.

（4）工具姿勢決定 $\cdot$ 残領域切除

圥長軸回転平面上の切除可能領域において，最終的な工具姿勢を決 定する. また，前項で決定した切除可能領域は全ての切除領域を網羅 しない可能性がある. 残領域がある場合は，この切除領域決定処理を 繰り返す。

\section{5. 結論と今後の課題}

本研究では，多軸の骨切除ロボットを用い，狭い開創領域から工具 を侵入させ，目的の骨切除を完了可能とする工具経路生成法を提案し た. 今後の課題は，(1)内部組織情報に基づく干渉回避アルゴリズム の検討，(2)アルゴリズムの実装，(3)切除実験による評価である. 最 終的には $8 \mathrm{~cm}$ の皮切長で周囲組織の損傷なしに切除を完了可能とする システムの構築を目標とする.

\section{文 献}

[1] 若山，森重，“工具姿勢変化の連続性を考慮した 5 軸制御加工用工具経路 生成法,”精密工学会, vol71, No. 5, pp. $639-643,2005$.

[2] 腰野富久, “人工関節置換術パーフェクトテクニック,”メジカルビュー社, 2000. 